\title{
RANCANG BANGUN SISTEM PERENDAMAN SESAAT YANG DILENGKAPI DENGAN SENSOR LEVEL
}

\author{
Asrizal Deri Futra*, Iwa Tama Putra*, dan Sumantri Kurniawan Risandriya* \\ *Jurusan Teknik Elektro, Politeknik Negeri Batam \\ Jl. Ahmad Yani, Batam 29461, Indonesia \\ E-mail: deri@polibatam.ac.id
}

\begin{abstract}
Abstrak
Sistem Perendaman Sesaat (SPS) merupakan salah satu teknologi pada kultur jaringan tumbuhan di mana jaringan tumbuhan direndam secara berkala. Pada saat perendaman, media cair mengalir dari wadah media cair ke wadah jaringan. Setelah proses perendaman selesai, media cair akan mengalir dengan sendirinya dari wadah jaringan ke wadahnya karena wadah media cair ditempatkan lebih rendah dibandingkan wadah jaringan. Sistem perendaman ini terdiri dari lima wadah media cair dan lima wadah jaringan yang dilengkapi dengan sensor level. Data waktu dan lama perendaman disimpan pada micro SD untuk melihat apakah SPS ini berjalan sesuai dengan waktu yang telah ditentukan. Pada saat proses perendaman, udara yang dialirkan menuju wadah media cair divariasikan 1 bar dan 1,5 bar untuk memindahkan air 254,5 $\mathrm{ml}$ yang ada dalam wadah media cair. Tekanan 1 bar sudah dapat mengalirkan media cair dari wadahnya ke wadah jaringan dan menimbulkan gelembung-gelembung air yang lebih sedikit dibandingkan tekanan 1,5 bar. Dari hasil data rekaman pada micro SD didapatkan bahwa waktu perendaman pada SPS ini sesuai dengan waktu yang telah ditentukan.
\end{abstract}

Kata kunci: Sistem Perendaman Sesaat, kultur jaringan tumbuhan, sensor level

\begin{abstract}
Temporary Immersion System (TIS) is one of technologies for plant tissue culture that the plant tissue is immersed temporarily. During the immersion period, the liquid medium flowed from the liquid jar to the tissue jar. After the certain time, the liquid medium would flow to its jar because the medium jars were placed below the culture jars. This immersion system consisted of five liquid medium jars and five tissue jars that integrated to level sensor. The data of immersion time and periods were recorded in micro SD to make sure that the system worked as time set. In the immersion process testing, the air pressures were varied, 1 bar and 1.5 bar to flow water of $254.5 \mathrm{ml}$ from the liquid medium jars to the culture jars. The pressure of 1 bar could drain the liquid medium from its jar to the culture jar and it caused less bubbles than 1.5 bar did. From the data recorded in micro SD, the time and duration of immersion was the same as time input.
\end{abstract}

Keywords: Temporary Immersion System, plant tissue culture, level sensor 


\section{PENDAHULUAN}

Sistem perendaman sesaat (SPS) atau Temporary Immersion System (TIS) merupakan salah satu cara yang digunakan untuk menumbuhkan jaringan tumbuhan dengan merendam jaringan tersebut secara berkala. Media cair dialirkan untuk memberikan nutrisi pada masa pertumbuhan jaringan tumbuhan tersebut. SPS ini dapat digunakan untuk berbagai jenis tanaman, seperti sagu [1,2], tebu [3], dan lain-lain. Ada beberapa jenis tipe SPS, yang salah satunya adalah tipe ebb-and-flow [4] yang mempunyai keunggulan, antara lain konstruksi dan automasi yang sederhana, serta menggunakan energi yang rendah [5]. Tipe ini menggunakan dua buah wadah tertutup, yaitu wadah untuk media cair dan wadah untuk jaringan tumbuhan. Kedua wadah tersebut dihubungkan dengan slang yang berfungsi sebagai jalur perpindahan media cair dari wadahnya menuju wadah jaringan, dan sebaliknya. Proses perendaman dilakukan dengan cara mengalirkan media cair dari wadahnya ke wadah jaringan. Setelah proses perendaman selesai, media cair kembali lagi ke wadahnya karena perbedaan posisi antara wadah kultur jaringan dan wadah media cair. Pada penelitian ini, penulis mengembangkan metode $e b b$ and flow dengan menambahkan sensor level yang bertujuan untuk memastikan apakah pada saat proses perendaman, media cair mengalir dari wadahnya ke wadah kultur jaringan dan setelah proses perendaman media cair kembali ke wadahnya. Tujuan penelitian ini adalah untuk membuat suatu sistem SPS yang waktu proses pengaliran media cair dapat dipantau dan diharapkan dapat digunakan pada kultur jaringan tumbuhan.

\section{METODE PENELITIAN}

SPS terdiri dari perangkat keras (hardware) dan perangkat lunak (software). Perangkat keras terdiri dari kompresor, valve, motor servo, wadah media cair, dan wadah jaringan. Kompresor digunakan untuk menyuplai udara ke wadah media cair. Valve digunakan untuk mengalirkan udara dan motor servo digunakan untuk membuka dan menutup valve. Gambar 1 menunjukkan blok diagram SPS.

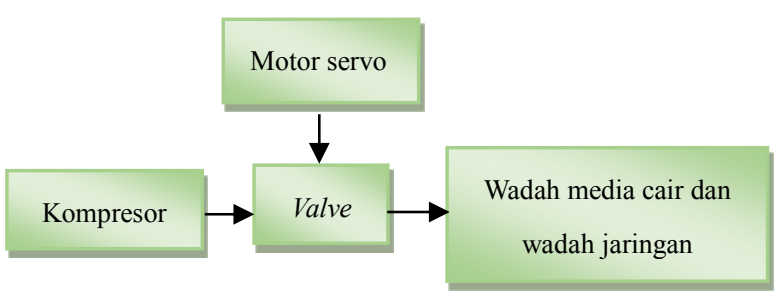

Gambar 1. Blok diagram SPS

Gambar 2 menunjukkan desain SPS. Wadah media cair dan wadah jaringan masing-masing terdiri dari lima wadah media cair dan lima wadah jaringan. Wadah media cair dan jaringan dihubungkan dengan slang untuk mengalirkan media cair dari wadahnya ke wadah jaringan, dan sebaliknya. Udara dialirkan ke wadah media cair yang kedap udara dengan tekanan yang cukup supaya media cair yang ada pada wadah tersebut dapat mengalir ke wadah jaringan. Selama proses perendaman, udara terus menerus dialirkan ke wadah media cair sesuai dengan waktu yang ditentukan. Setelah proses perendaman selesai, pengaliran udara ke wadah media cair dihentikan sehingga media cair yang mengisi wadah jaringan mengalir kembali ke wadahnya tanpa memberikan udara pada wadah jaringan. Hal tersebut disebabkan posisi wadah media cair diletakkan lebih rendah dibandingkan wadah jaringan. Untuk memastikan media cair tersebut mengalir ke wadah jaringan dan kembali lagi ke wadahnya, maka diletakkan sensor level pada masing-masing wadah jaringan.

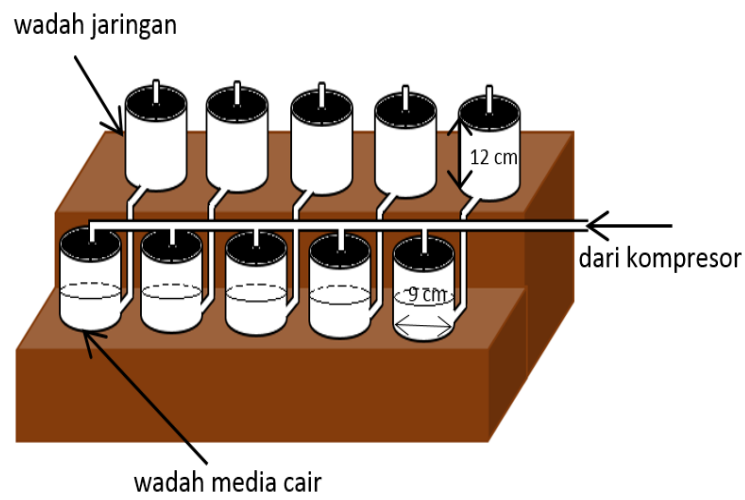

Gambar 2. Desain SPS

Perangkat lunak (software) dibuat dengan menggunakan software arduino yang digunakan untuk menentukan kapan waktu perendaman dilakukan dan 
lama perendaman. Gambar 3 menunjukkan diagram alir program yang digunakan untuk memantau pengaliran media cair.

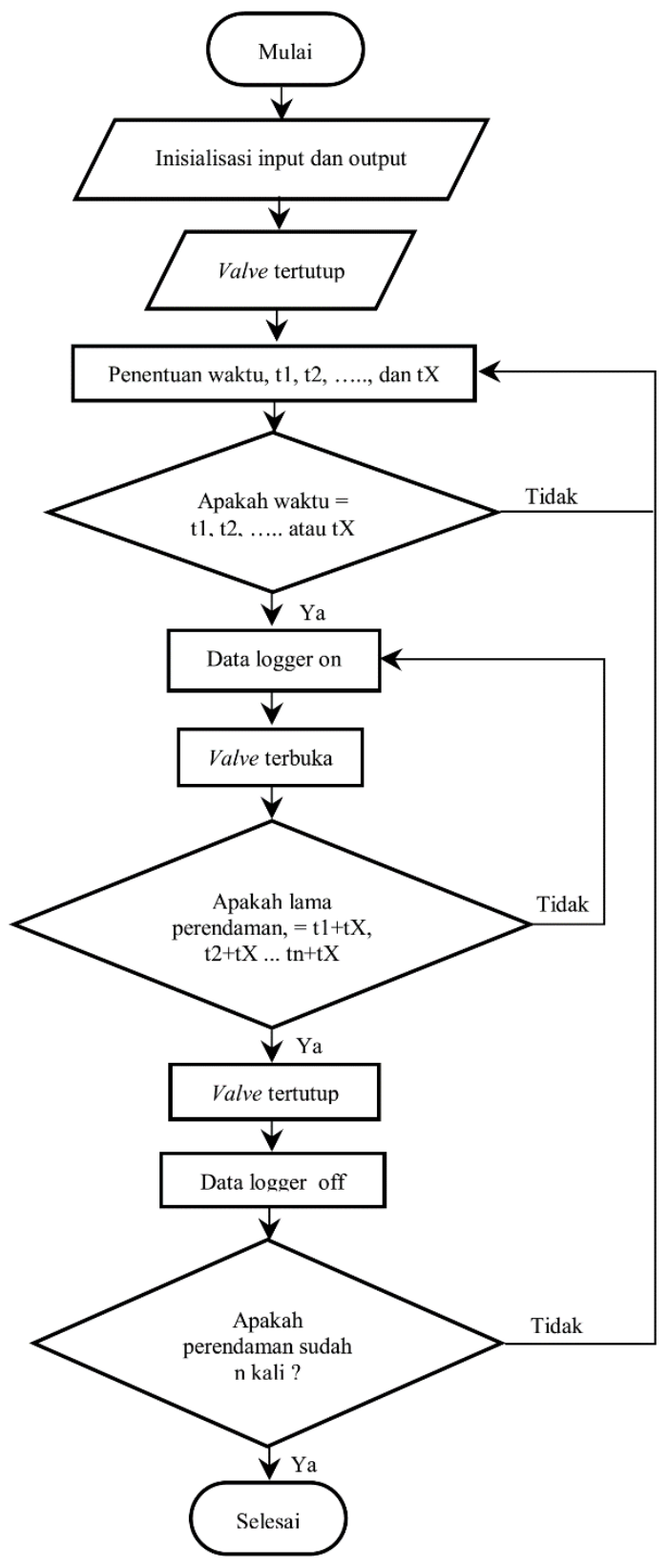

Gambar 3. Diagram alir program SPS

Pada awalnya, valve dalam kondisi tertutup, sehingga tidak ada udara yang mengalir dari kompresor ke wadah media cair. T1 dimasukkan untuk menentukan kapan waktu perendaman dilakukan dan $\mathrm{tX}$ dimasukkan sebagai lamanya proses perendaman. RTC DS3231 digunakan untuk mengetahui waktu secara real time sehingga waktu perendaman dapat dibandingkan dengan waktu pada
RTC. Ketika waktu perendaman sama dengan waktu pada RTC, motor servo akan membuka valve sehingga udara mengalir dari kompresor menuju wadah media cair dan mengalirkannya ke wadah jaringan. Selama proses perendaman, valve selalu terbuka. Selain itu, pada saat waktu pada RTC sama dengan t2, t3, dan seterusnya maka data logger akan on untuk merekam waktu ketika valve terbuka dan tertutup kembali. Data tersebut disimpan menggunakan micro SD. Setelah proses perendaman selesai, motor servo berputar berlawanan arah untuk menutup valve, dan media cair mengalir kembali ke wadahnya. Proses tersebut terus berlanjut sampai dengan waktu yang ditentukan.

\section{HASIL DAN PEMBAHASAN}

Gambar 4 menunjukkan sistem perendaman kultur jaringan yang terdiri dari sepuluh wadah, yaitu lima wadah media cair dan lima wadah jaringan. Dari gambar 4 terlihat bahwa posisi wadah media cair lebih rendah dibandingkan dengan wadah jaringan. Sensor level diletakkan pada masing-masing wadah jaringan untuk memastikan media cair mengalir dari wadah media cair ke wadah jaringan, dan sebaliknya.

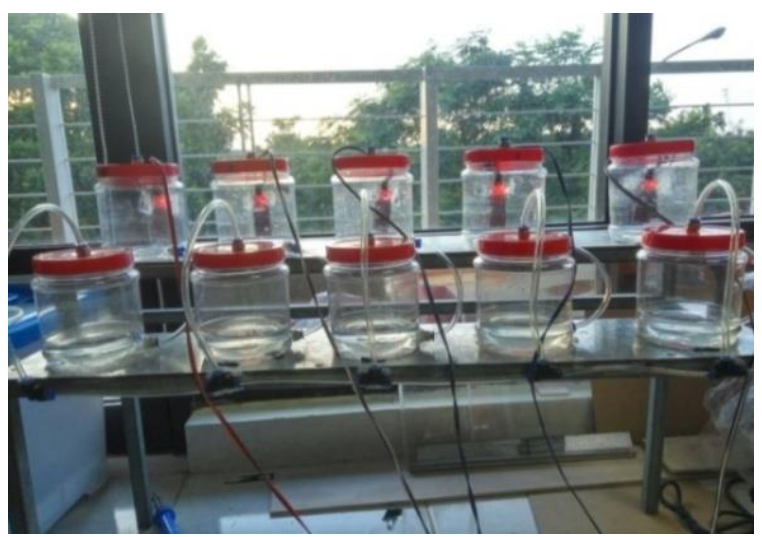

Gambar 4. Sistem perendaman sesaat kultur jaringan

Pengujian sistem yang telah dibuat dilakukan dengan cara mengatur tekanan udara yang mengalir dari kompresor dengan menggunakan regulator dan menentukan kapan proses perendaman berlangsung dan lama perendaman tersebut. Untuk pengujian, air dengan volume 254,5 $\mathrm{ml}$ digunakan sebagai media cair. Pengujian sistem udara dilakukan untuk mengetahui seberapa besar penggunaan udara untuk sistem ini. Tekanan udara yang digunakan untuk 
mengalirkan media cair ke wadah jaringan divariasikan 1 dan 1,5 bar. Gambar 5 menunjukkan waktu rata-rata yang dibutuhkan untuk mengalirkan media cair ke wadah jaringan.

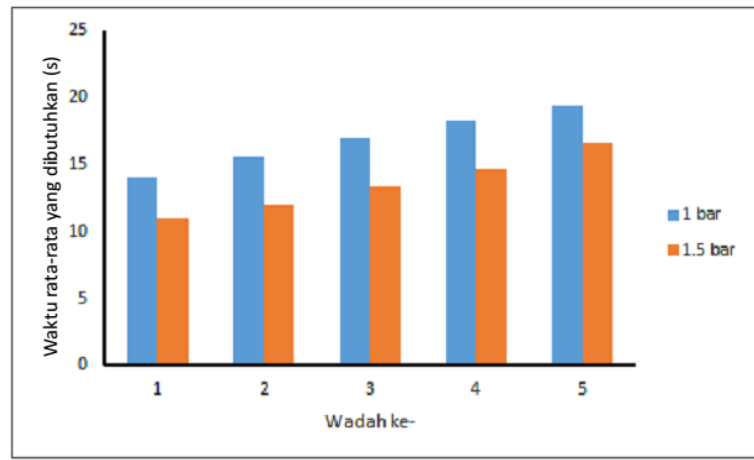

Gambar 5. Hubungan antara waktu yang dibutuhkan dengan wadah ke- (proses pengaliran media cair ke wadah kultur jaringan)

Jika tekanan 1 bar digunakan untuk memindahkan media cair dari wadah media cair ke wadah jaringan, waktu yang dibutuhkan untuk mengalirkan media cair dari wadah media cair pertama adalah 14 detik sedangkan untuk tekanan 1.5 bar, waktu yang dibutuhkan adalah 11 detik. Waktu ini merupakan waktu yang paling cepat dibandingkan dengan waktu yang dibutuhkan untuk mengalirkan media cair pada wadah lainnya. Hal ini dikarenakan distribusi udara untuk masing-masing wadah tidak sama. Tekanan 1 bar memberikan aliran yang lebih stabil dibandingkan tekanan 1,5 bar. Hal ini dikarenakan pada tekanan 1,5 bar, aliran udara yang keluar sangat deras sehingga menimbulkan gelembung-gelembung air yang banyak. Setelah proses perendaman selesai, air yang berada pada wadah jaringan akan turun dengan sendirinya karena posisi wadah media cair berada lebih rendah dari wadah jaringan.

Gambar 6 menunjukkan grafik hubungan antara waktu yang dibutuhkan media cair mengalir kembali ke wadah kultur jaringan terhadap masing-masing wadah. Dari gambar 6 terlihat bahwa waktu yang dibutuhkan untuk kembalinya media cair ke wadahnya tidak sama.

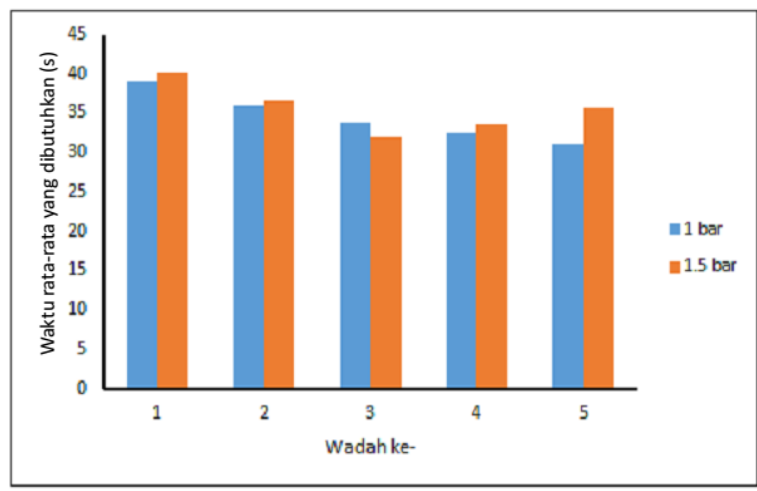

Gambar 6. Hubungan antara waktu yang dibutuhkan dengan wadah ke- (proses kembalinya media cair ke wadahnya)

Pengujian waktu perendaman ini untuk memastikan apakah proses perendaman berjalan dengan baik sesuai dengan waktu yang telah ditentukan. Pada pengujian ini sistem dijalankan enam kali dalam sehari selama seminggu dengan lama waktu setiap perendaman adalah satu menit.

Tabel 1. Pengujian sistem waktu perendaman

\begin{tabular}{|c|c|c|c|c|c|c|}
\hline $\begin{array}{c}\text { Hari/ } \\
\text { Tanggal }\end{array}$ & $\begin{array}{c}0: 00 \\
\mathrm{~s} / \mathrm{d} \\
00: 01\end{array}$ & $\begin{array}{c}04: 00 \\
\mathrm{~s} / \mathrm{d} \\
04: 01\end{array}$ & $\begin{array}{c}08: 00 \\
\mathrm{~s} / \mathrm{d} \\
08: 01\end{array}$ & $\begin{array}{c}12: 00 \\
\mathrm{~s} / \mathrm{d} \\
12: 01\end{array}$ & $\begin{array}{c}16: 00 \\
\mathrm{~s} / \mathrm{d} \\
16: 01\end{array}$ & $\begin{array}{c}20: 00 \\
\mathrm{~s} / \mathrm{d} \\
20: 01\end{array}$ \\
\hline $\begin{array}{c}\text { Rabu/ } \\
13-12-17\end{array}$ & \multicolumn{7}{|c|}{} & $\sqrt{ }$ & $\sqrt{ }$ & $\sqrt{ }$ \\
\hline $\begin{array}{c}\text { Kamis/ } \\
14-12-17\end{array}$ & $\sqrt{ }$ & $\sqrt{ }$ & $\sqrt{ }$ & $\sqrt{ }$ & $\sqrt{ }$ & $\sqrt{ }$ \\
\hline $\begin{array}{c}\text { Jum'at/ } \\
15-12-17\end{array}$ & $\sqrt{ }$ & $\sqrt{ }$ & $\sqrt{ }$ & $\sqrt{ }$ & $\sqrt{ }$ & $\sqrt{ }$ \\
\hline $\begin{array}{c}\text { Sabtu/ } \\
16-12-17\end{array}$ & $\sqrt{ }$ & $\sqrt{ }$ & $\sqrt{ }$ & $\sqrt{ }$ & $\sqrt{ }$ & $\sqrt{ }$ \\
\hline $\begin{array}{c}\text { Minggu/ } \\
17-12-17\end{array}$ & $\sqrt{ }$ & $\sqrt{ }$ & $\sqrt{ }$ & $\sqrt{ }$ & $\sqrt{ }$ & $\sqrt{ }$ \\
\hline $\begin{array}{c}\text { Senin/ } \\
18-12-17\end{array}$ & $\sqrt{ }$ & $\sqrt{ }$ & $\sqrt{ }$ & $\sqrt{ }$ & $\sqrt{ }$ & $\sqrt{ }$ \\
\hline $\begin{array}{c}\text { Selasa/ } \\
19-12-17\end{array}$ & $\sqrt{ }$ & $\sqrt{ }$ & $\sqrt{ }$ & $\sqrt{ }$ & $\sqrt{ }$ & $\sqrt{ }$ \\
\hline $\begin{array}{c}\text { Rabu/ } \\
20-12-17\end{array}$ & $\sqrt{ }$ & $\sqrt{ }$ & $\sqrt{ }$ & & & \\
\hline
\end{tabular}

Keterangan: $\vee$ : Sistem berjalan

Dari tabel 1, terlihat bahwa sistem mulai dijalankan pada hari Rabu, 13/12/17 jam 12 siang, dan pengujiannya berakhir pada hari Rabu, 20/12/2017 jam 8 pagi. Secara keseluruhan sistem berjalan sesuai yang diinginkan sebanyak 42 kali. Ketika waktu pengaliran sama dengan waktu yang tertera pada LCD, maka proses pengaliran berlangsung selama selang waktu 1 menit. Sistem berjalan enam kali setiap hari dan terus berulang selama satu minggu. 


\section{KESIMPULAN}

Sistem Perendaman Sementara (SPS) yang dilengkapi dengan sensor level telah dibuat. SPS ini diuji dengan menggunakan tekanan 1 bar dan 1.5 bar. Dari hasil pengujian, tekanan udara 1 bar merupakan tekanan yang paling cocok yang digunakan pada SPS ini untuk mengalirkan media cair dari wadah media cair ke wadah jaringan karena tekanan 1 bar telah dapat memindahkan media cair ke wadah jaringan dan menimbulkan gelembung-gelembung air yang lebih sedikit daripada tekanan 1,5 bar. Pada pengujian waktu proses perendaman, waktu dan lama proses perendaman pada rancang bangun SPS ini sesuai dengan waktu yang telah ditentukan.

\section{REFERENSI}

[1] Kasi, P.D., Sumaryono, "Perkembangan kalus embriogenik sagu (Metroxylon sagu Rottb.) pada tiga sistem kultur in vitro", Menara Perkebunan, vol.76(1), pp. 1-10, 2008.

[2] Riyadi. I., Efendi, D., Purwoko, B.S., Santoso, D. "Embriogenesis Somatik Tidak Langsung pada Tanaman Sagu (Metroxylon sagu Rottb.) Menggunakan Sistem Kultur Suspensi, Perendaman Sesaat, dan Media Padat", Jurnal AgroBiogen 12(1):37-4.

[3] Minarsih, H., Riyadi, I., Sumaryono, Budiani, A., "Mikropropagasi tebu (Saccharum officinarum. L) menggunakan sistem perendaman sesaat", Menara Perkebunan, vol. 81(1), pp. 1-8, 2013.

[4] Ducos, J.P., Terrier, B., Coutois, D., and Pétiard, $\mathrm{V}$, "Improvement of plastic-based disposable bioreactors for plant science needs," Phytochemistry Reviews, vol. 7, pp. 607-613, 2008.

[5] Georgiev, V., Anika, S., Atanas, P., Bley, T., "Temporary immersion systems in plant biotechnology", Engineering in Life Sciences, 14, pp. 607-621, 2014. 